\title{
Realization of Human Security in Light of Good Governance
}

\author{
Maedeh Samadi ${ }^{1} \&$ Seyyed Bagher Mirabbassi ${ }^{2}$ \\ ${ }^{1}$ PhD Student in International Law, Department of Law and Political Science, Science and Research Branch \\ Islamic Azad University, Qeshm, Iran \\ ${ }^{2}$ Professor, Department of Law and Political Science, University of Tehran, Tehran, Iran \\ Correspondence: Seyyed Bagher Mirabbassi, Professor, Department of Law and Political Science, University of \\ Tehran, Tehran, Iran. E-mail: mirabbassi@parsilo.com
}

Received: September 4, 2016 Accepted: October 2, 2016 Online Published: December 29, 2016

doi:10.5539/jpl.v10n1p84 URL: http://dx.doi.org/10.5539/jpl.v10n1p84

\begin{abstract}
Support of human rights and the appearance of "human security" issue in the new system of international law as a newfangled concept, has led to a change in traditional outlook towards security. In the present paper beside taking into consideration the concept of security in Realist and Liberal Perspectives, the developmental performance of the state regarding enforcement of rules (as the first serious addressee of providing and guaranteeing human rights in international rights system) from national security with a focus on human security in the context of good governance was considered as well. The primary objective of the study was to understand the effect of good governance on human security realization. In such a way that states would be able to increase the coefficient of human security provision and guaranty by changing the method of governance in their territory. Also, reforming the governance structure besides taking steps to strengthen individuals in the face of human insecurity is also a coherent approach to providing a helpful background for civil society.
\end{abstract}

Keyword: state, national security, good governance, human security, human rights

\section{Introduction}

The new international law system is the product of a process which looks for international relations not only in relations between states, but beyond that and in intergovernmental relations and ties between the state and people. During the last fifty years, a change in the individual's status can be observed as the holder of rights under international law system. According to Antonio Cassese an individual can consider similar rights for each one of the explicit international obligations of the individual in a complete way, by following some important values (peacekeeping, protection of human dignity and so on). He emphasizes that this issue is not only from the outlook of legal logic, but is compatible in conformity with modern methods in the global world; that regarding those obligations, international law belongs to all persons, and they deserve the respect due to their lives and body members and dignity. Therefore, they have the right not to be a victim of war crimes, crimes against humanity, rape, torture and terrorism (Giorgio Gaja, 2010, p.11)2. With an emphasis on the human dimension of international law, especially human rights a path is paved for the promotion of the individual's role in the international system, in light of which it is possible to discuss the most basic needs of the human i.e. freedom from fear, poverty, need and comprehensively human security. It is also essential to talk about governance of states in national and international fields with an emphasis on the least criteria required for a collective life in along with peace and security. It is supposed that realization of human security is not achieved in a society and a state's territory except by good governance which exerts fundamental human rights. Therefore the state demands a respondent that by bringing into force the items of good governance facilitates the grounds of human security realization. In this regard first the concept of security, specifically human security is discussed and besides proposing theoretical grounds of the discussion, capability of states in the orientation of the human security approach which is the same as desired item i.e. good governance is considered.

\section{Explaining Concept of Security}

Security is principally referred to a type of psychological feeling in which being freedom of fear leads to a situation of relaxation and confidence. Attempt to achieve "secure position" is the basis for the formation of political units so that by the cooperation of members of the mentioned societies they can obtain their most pressing need, i.e. security provision. Nevertheless, in primary societies and even until the end of the 1980s, the 
approach to the security was a restricted outlook with the main focus on military fields. In other words, there was a kind of reductionist approach towards security which was looked for in military capabilities and peacemaking attempts after the wars (Buzan, 1999, p. 23).

By elapse of time and due to changes happening in human needs and expectations, new variables appeared in security definition. For instance, at present the event called environmental degradation is one of the important factors destroying human security; this is while some years ago such a factor was not considered at all. From the beginning of the Westphalian system until the recent decades, international security was mainly defined in the form of military security; but nowadays the focus on military security is being questioned, and global security is defined in different political, military, economic and social dimensions. The term of 'security' has no meaning without the existence of the element of 'threat'. If defined in a more simple way, security means the optimal use of opportunities to eliminate threats. By taking into consideration all these definitions, it can be concluded that security emanates from the two essential elements of risk and opportunity. Security in the first place is leaned toward law. By law, security is created from stability as well as the predictability of reactions. The need for security is in the first place supplied by developing a legal system. The very first responsibility of this system is to establish 'order' in the society along with legislations and rules that have an adequate performance bond. This kind of security is created by law. (Personal Legal Security) (Falsafi, 2011, p. 412) In addition to the field of law, security is considered as an undeniable necessity in all areas of social relations including morality, economy, sociology and anthropology and its essentiality is proved. Human security is the issue considered by the present research which is the main connection reason between the two fields of security and development which has serious effects and consequences in both domestic and international scopes.

\section{Theoretical Foundations of Human Security in Realist and Liberal Perspectives}

Studying heroic myths of Heroes such as the Goddess and God of Gods in Greece Mythology clarifies that need for security besides other primary needs of humanity, such as the need for support, justice, and law, is also included in the category of fundamental human needs (Sane Pour, 2000, p. 21). Human biology in its natural condition which was a period without security and stability led him towards social setting and following that establishment of state and government. After granting power to the state, cooperation and securing the environment were considered as arrangements to protect people against natural disasters. With the passage of time in the field of state-individual relationships regarding public law and criminal issues, guaranteeing the individual's personal rights was made possible in the first rank through adequate protection of the individual against state interventions in private relations and the second ranks through prediction of some rules to prevent unjust restriction of these rights. In most free thought systems of the world, the category of these guarantees is named as fundamental freedoms (Falsafi, 1999, p.406). Concepts of positive and negative liberty were also created regarding intervention or non-intervention of the state in providing human needs and protecting his freedoms and rights (Berlin, 1990, p. 237). As time went on the traditional regime of international law, having a state oriented outlook, face some challenges while confronting with the new law system having human-oriented prospects. It is essential to pay attention to the element of security in Realist and Liberal perspectives to face this challenge and understand it better. Realist perspective paves the way for processing a theory which considers and discusses an important collection of threats against the survival of the state and its territory. The theory is based on this belief that state and territory are the purposes of a major source of security and the most significant threat to them is a different discipline threat. From the viewpoint of Realism, the state is considered as the major issue or the only security one, and the concern is protecting it from foreign threats. In Realist perspective, the state is the major issue of security because it is the highest source of authority in an Anarchic international system and also the security of individuals is dependent on the state's security. Individuals are important, but the state needs to provide its security first and then provide individuals' security. Security of states is also necessary for human security because it is often expected from a secure state to ensure the safety of its people in the best way. Even dishonest and dysfunctional governments usually provide a significant level of security to survive its citizens' life and property, and this issue in its turn has drastically reduced the pressure to replace the international government with international natural position (Sharifi, Taraz Koohi, 2003, p. 56).

According to the School of Liberalism, the relation between human and nature is not a clear relationship. Human and nature require in essence separate from each other and freedom a human to be the ruler of his soul.Of course nature, the world, others and shortcomings of soul affect human, but do not foreclose his determination. This type of relationship existing between human and nature and their mutual interactions represents manifestations of the insecure world in an exact way. Evil (badness, insecurity, agony and misery) is a driving force that feeds on our freedom and ignorance, but at the same time makes the society move forward and guarantee its survival. Evil intervenes in the work of the order; in such a way that it makes the society think of an arrangement to drive 
it away. The purpose of a free thought society does not satisfy expectations of people but to create security, i.e. guaranty law (Falsafi, 2011, p.403). In Liberalism perspective security is not state-oriented and focuses on human security and therefore issues such as terrorist movements, economic and environmental threats are also placed under the category of security.

\section{Human Security Paradigm Plan in International Law System}

Interpretations of freedom from fear and freedom from fear were proposed in the January 6th, 1941 in a speech given by Roosevelt in Congress and in the form of a part of Outlook which is of the world dependent upon Four Freedoms of Mankind. From among the four freedoms introduced by President Roosevelt, two of them shaped the foundations of United States formation in 1945: freedom from fear and freedom from want. These two concepts formed pillars of universal human rights and became famous as "generation."

(www.humansecurityinitiative.org/definition-human-security). During the cold war years, Western countries were insistently looking for providing political and civil rights (freedom from fear), while the Soviet block and post-colonial developing countries were looking for the second generation, i.e. the economy and development rights (freedom from want). With the end of cold war, in human development report of UNDP, an attempt was made to create a compromise between these two concepts and concept of human security was invented with the aim of simultaneous inclusion of freedom from fear and freedom from want (Tajbakhsh, 2008, p. 19). In 1994 the term 'human security' was proposed by Mahbub U1 Haq, the Pakistani economist, and diplomat and special advisor of the United Nations Development Program. In his United Nations Development Program's Human Development Report with a focus on freedom from want and fear as solutions to eliminate insecurity in the world; and following that it was taking into consideration in the foreign policy of some states. According to Mahbub Ul Haq, human security is not about countries and nations but persons and individuals. Also on this basis, he reasons that the world has entered a new era of human security in which the meaning of security will change. According to this new concept, security refers to individuals' security and not just the security of nations and territory. Human security in reflected in the lives of people and their countries' guns (Bajpai, Kanti, 2003, p.219)13. After the end of cold war and the collapse of the Soviet Union and proposal of new discussions in the field of security research, the idea of human security was shaped through the connection of the two areas of development and security (Krause, Keith, 2003, p. 43). In 1994 following the United Nations report regarding the development program, economic and political experts attended this idea more than before. Human security by having the features of "universality", "deterrence" and "Human-center" classifies threats, focusing on a human being in 7 categories as follows: individual, society, policy, economy, food, hygiene and environment (King, 2002, p. 589). The idea of human security was suggested to solve problems and difficulties of the state-centered situation of security concept. The reason is that in one hand state is the foundation of human security and on the other hand is one of the primary sources of insecurity. The important definitions given for 'human security' are as following: human security is being away from all threats that endanger human survival, his daily life, and personality; threats such as environmental degradation, human rights violation, organized crimes, drug trafficking and continuous attempt to fight against these threats is also a part of the human security process (King, 2002, p. 592). Human security is about protection of people from grave dangers that threaten life; disregard of the root of threat exists, whether in human activities or natural events; whether they are hidden inside or outside the state or whether they are direct and without intermediary or structured (Kor, 2008, p. 607). Human security is freedom from want, freedom from fear and respect for human dignity to participate in social activity. The goal of human security is to protect living essence of all human beings against prevalent threats (Gasemi, 2005, p. 818). Human security of every individual refers to "years of life expectancy without being in generalized poverty" (King, 2002, p. 592). Protecting individuals and communities from war and other types of violence (Kor, 2008, p. 606).

The narrow definitions of human security focus on traditional threats of security, such as violence and disputes, but broad definitions include freedom from fear and want and threats such as poverty and the environment. The United Nations Commission gives a definition of human security as follows: protecting the core and essential foundations of human life through executing human freedoms. Human security means protecting fundamental freedoms or in other words the freedoms which are the foundation of life. Protecting people against serious and widespread threats means utilizing a process which realizes talents and desires of the people; using a process that leads to the creation of political, social, environmental, economic, cultural and military systems that in total create survival, livelihood, eminence, and dignity. This definition passes the state-centered concept of security which focused on military attacks and considered the security of humans, his protections, and strengthening. This definition involves drawing of multiple threats that endanger diverse aspects of human life in three fields of security, development and human rights (Burgess, J. Peter, and Taylor Owen, 2004, p. 345). It also contains 
promotion of an integrated, concentrated and people-centered approach that develops peace, security, and development.

Different types of threats affecting human security in daily life are as follows:

Economic security (persistent poverty, joblessness), food security (hunger and famine), health security (deadly infectious diseases, unhealthy food, malnutrition, lack of access to primary health care), environmental security (environmental degradation, reduction of resources, natural disasters, pollution), personal security (physical violence, crime, terrorism, domestic violence, child labor), society security (internal, ethnic, religious and racial tensions), political security (political repression, human rights abuses) (Based on the UNDP Human Development Report of 1994 and the HSU-OCHA). Human Security has determined principles; in the first place, it is human-centered (comprehensive and cooperative focusing on want and vulnerability of individuals and society and performing the active factors specifies insecurities which threaten natural resources including local capital and fundamental confronting mechanisms). It is multidimensional (considering multiple sections through promoting debate and interaction among principal actors, assisting to ensure consistency and harmony among sectors and traditional separates grounds, evaluating positive and negative lateral effects of each one of the answers regarding a human security situation that influence society), comprehensive (in-depth analysis: the seven elements of security in human security, attention to a wide range of threats, vulnerability and capacity, analysis of players and sectors not considered before and are related to the success of a program or project. Expanding multi-sector response/multiplayer, having a unique framework (the need for a deep analysis of the status of the goal) and precautionary (detection of dangers, threats, and reaction regarding its reasons, focus on prudent response through strengthening and protective framework).

It is required to outline a goal, have an overall planning and execute and perform that in the primary stage of analysis, mapping, and planning to realize and provide human security. In other words, it is necessary to create participatory and collective processes of identifying requirements, vulnerability, and capacities of a society which is affected- insecurity plan by actual vulnerabilities and capacities with fewer focus on what is possible and more emphasis on what is actual needed. Creating a priority through needs includes the following items.

Vulnerability and analysis of capacity about the suffering society.

Detection of the root causes of insecurity- group insecurity based on overall and multi-section mapping and taking care of side effects.

Creating strategy and responses which a combination of capability and supportive actions.

Short and medium general view and long term plan of results even if they are not executed in special programs.

Drawing a strategy in different stages with a society that is a necessary foundation for sustainability.

Creating a multi-player planning to ensure the solidarity of the goals and attribution of responsibilities and duties.

The second stage includes execution (execution in cooperation with local partners- the capacity building of society and local institutions- supervision as a part of the program and a basis for learning and adaptation) and finally the stage of the evaluation (Are we executing a suitable plan in the confrontation of what is called insecurity?

Does this plan reduce the recognized human insecurity while at the same time avoids its negative lateral effects? (http://ochaonline.un.org/humansecurity, HUMAN SECURITY IN THEORY AND PRACTICE 2009). Extracting the experiences gained from failures, successes, and improvement of plans and considering a broad range of threats that attack human security is in first place related to the state. It is the responsibility of state that by discussing proper principles and approaches to provide grounds for realization, provision and execution of human security as the perfect feature of human rights guaranty in the light of good governance.

\section{Good Governance as a Critical Necessity for Human Security Realization}

Human rights and good governance are both important parts of the human security concept and mutually strengthen each other. It is an important issue and has a close connection with the role of democracy in promoting human security and also in solidification of (government through dialogue), it is likewise democracy that its success in preventing famines is rooted in its multidimensional role-playings in solidification of human security (Sen, 2012, p. 434). Discussing the role of states in human security realization in society requires giving attention to power exert processes in society. Economic, social and cultural rights (called the second age of human rights indicating demand rights or requesting abilities) include the provision of financial and physical security causes in the real and imagined world of society sections. In this generation, we are faced with a change 
in comparison with the first generation of human rights regarding the role of the state in providing freedoms; in this respect, considering the element of good governance and saying its features to clarify the role of states will be useful. The rule of law is one of the essential components of good governance and human rights, freedom and equality is also bases of the rule of law. The central presumption of the rule of the law is the individuals having rights being highly ethical in nature and on the other hand, the theory of the rule of law is looking for guaranteeing exertion of citizen rights through reliable mechanisms of law. In this way, the rule of law is considered as one of the guarantees of human rights effort (Merkez, Malmiri, 2006, p. 92). The behavior of leaders and governmental administrates in bringing social atmosphere or a particular situation to the level of expectations caused by principles as mentioned above, is considered an active factor (Tamushat, 2007, p. 148).

One of the indices of good governance is that governments keep their citizens secure. Enacting different and sometimes contradictory laws violates benefits of individuals and groups. Good governance attempts to reduce such costs. Institutionalizing Participation is among important strategies in creating good governance; especially the participation of poor people in events and processes that constitute their lives can be one of the ways to strengthen them against poverty. Decentralization is also one of the elements of good governance, which make people and government closer. By good governance indices, managing public affairs are done through the pass of the rule of law, transparency, flexibility, equality, participation in the light of efficiency system and framework of efficient management accompanied with responsiveness. According to the criteria and experienced and scientific principles, it is not only exposed to the judgment of professionals, but in the light of consciousness and sensitive public thoughts. Based on features of such an item and its development as a behavior pattern among committed governments, the effect of good governance role in the provision and assurance of human security can be emphasized. If the main responsibility of human security realization is supposed to be a national duty and upon state, then fulfilling this obligation requires good governance in national level.

Timely investments on life skills and abilities guaranty a better life. However, the lack of timely and continuous investments in life skills can drastically affect the abilities of the individual in achieving his perfect growth. If social and legal institutions, power structures, political environments and our cultural-social and traditional norms do not give services to the members of society while observing equality and create structural barriers in the pass of realization of rights and decisions of some people and groups, then in practice the structural vulnerabilities will escalate (Marashi, 2014, p. 2).

Tolerating vulnerability requires the presence of responsive institutions. The existence of policies and sufficient resources to provide jobs, health care centers and training opportunities, especially for the poor and vulnerable people is essential. Countries that take measures to reduce inequality among groups can act better regarding the principle of universal coverage and develop social solidarity and prevent crises and if happened, manage them. The role of responsive governing institutions is critical to overcoming the feeling of injustice, vulnerability, and isolation which can spread social dissatisfaction. Civil cooperation and mass mobilization, in their turn, are essential in guaranteeing acknowledgment of interests and rights of vulnerable people by states (Marashi, 2014, p. 11).

Countries can exert a combination of interventions and policies to reduce horizontal inequality. Rules based on the law may lead to drastic improvements for vulnerable groups that due to malfunctions of institutions can enjoy legal supports and public pursuits. Change of norms to escalate tolerance and strengthen social solidarity is one of the necessary aspects of making resistant societies. Highly cohesive communities act better in protecting individuals against unfavorable events and accept better policies based on the principle of universal coverage. Execution of good governance indices can wipe out the barriers and challenges to achieving human security and be used for its performance as an efficient tool. States can improve their capabilities by strengthening their institutions. That requires institutionalizing the laws and norms that motivate government authorities so to act in the collective interest (Mubarak, 2010, p. 179).

\section{Conclusions}

Being secure is one of the most significant and clear instances of fundamental human rights and a prerequisite for the realization and enjoyment from any other right. By connecting good governance and sustainable human development, principles such as participating, accountability and human rights promotion are emphasized. Good governance approach, as a value-based approach with a focus on concepts such as accountability, transparency, equality and social justice, is for organizing social affairs and accelerating efficient development. This method can provide favorable conditions for solving problems of developing countries, especially by modifying law system, provoking public participation, market development, the participation of civil institutions and increasing transparency. 
Insecurity of people who are faced with structural vulnerabilities extends over an extended period and leads to gender, ethnic, racial, occupational and social status separation which cannot be solved quickly. The power of tolerance and resiliency is the basis of human development sustainability and assurance approaches. Reducing vulnerability in the face of threats through methods such as modification of governing structure is not only taking steps to strengthen people in the face of problems, but is also a coherent approach to preparing grounds for the participation of civil society and private section. Governing improves if citizens take part directly in it. At this close relationship, states can obtain precise information regarding the vulnerability of people and analyze effects of their interventions. As Article 2 of the international economic, social and cultural covenant enacted on 1966 emphasizes on utilizing the maximum existing resources with the aim of the gradual provision of the complete acts of law, such participation will lead to the efficient intervention of states and optimal use of public resources. Effective participation was realized at the time when people that have freedom, security, capability and power can intervene in decision makings.

It should be mentioned that the human security agenda needs social engineering capacity, which requires sufficient resources and or political determination to pursue it, and sometimes the states select the items from human security agenda that are by their national interests. Plato states in his book 'Republic' that: "Our rulers will have no choice but to lie and cheat to supply fortune and happiness of their inferiors; such kind of lies have medicinal character" (Fen Tigershetrum, 2013, p. 51). Because states do not always protect their people's security and in some cases even threaten it. The program of good governance and emphasis on it is to eliminate such kind of shortcomings to guaranty human security realization. Therefore the responsibility that policy makers are to take is very critical. In this regard, Dan Hank believes that: the players at this stage need to have a long-term vision for the future interests. The human security agenda needs to be the frontispiece of states' performance and utilizing the law in light of good governance as a tool to move forward. International agreements about weapons, transnational organized crime, drugs, and terrorism, are all looking for responding such threats that targeted human security. A wide range of binding and non-binding documents are created to cease various kinds of threats beyond physical violence. Threats such as poverty, infectious diseases, environmental degradation, water crisis and natural disasters. Therefore a secure state will not exist if its people live in insecurity. States, whether in the position of the legislator and domestic executor (good governor) or as a member of active members of the international law system are accountable to make intelligent policies to prevent threats and codify protective programs to respond vulnerability of different groups of people. Since human is the primary and final beneficiary of the international law system and focuses on the individual is of inherent components of human security. Therefore, it requires particular attention to the wants and interests of people and believes that interests and desires of individuals are before interests and wants of states.

\section{References}

Alkire, S. (2003). A Conceptual Framework for Human Security. Working Paper 2. Oxford: Centre for Research on Inequality, Human Security and Ethnicity (CRISE).

Bajpai, K. (2003). the idea of human security, international studies.

Berlin, A. (1990). Four Articles About Freedom, Translated by Muhammad Ali Movahhed, Kharazmi Publication.

Burgess, J. P., \& Owen, T. (2004). Editors' Note, Special Section: What is Human Security? Security Dialogue, 35(3), 345-346. https://doi.org/10.1177/0967010604047569

Falsafi, Hedayat-Ul-Allah. (2011). Eternal Peace and the Rule of Law, Farhange Nashre No, Tehran.

Fen Tigershetrum, B. (2013). Human Security and International Law, Tranlated by Ardashir Amir Arjmand, Majd Publication.

Gasemi, M. A. (2005). Human Security: Conceptual Bases and Strategic Requiremnets. Journal of Strategic Studies, (4).

Giorgio, G. (2010). The Position of Individuals in International Law: An ILC Perspective. European Journal of international law Issue, 21(1).

King, G., \& Christopher JL Murray. (2002). Rethinking Human Security. Political Science Quarterly, 116(4).

Krause, K. (2007). Towards a Practical Human Security Agenda. Policy Paper 26. Geneva: Geneva Centre for the Democratic Control of Armed Forces (DCAF).

MacRae, R., \& Hubert, D. (Eds.). (2001). Human Security and The New Diplomacy: Protecting People, Promoting Peace. Montreal and Kingston: McGill-Queens University Press. 
Merkez Malmiri, A. (2006). The Rule of Law (1st ed.). Tehran, Research Center of Iran's Parliament.

Miri, A. (2006). An Introduction to Theory of Good Governance. Period, 6(22).

Mubarak, A., \& Azar Peyvand, Z. (2010). A Glance at the Features of Good Governance in View of Islam and its Effect on Economic Growth. Journal of Islamic Economy, 9(36).

Plato. (1974). Republic, Translated by Lotfi, Muhammad Hassan, Ibn Sina Publication.

Saane Poor, M. (2012). Greek Mythology and Western Modernity. Human Sciences and Cultural Studies Research Center.

Sen, A. (2012). Thought of Justice, Translated by Hussein Sharifi Taraz Koohi, Tehran, Mizan Publication, First Edition.

Sharifi Taraz Koohi, H. (2001). Human Rights Theories and Approaches (1st ed.). Publication of Political Sciences and Law Faculty of Tehran.

Suhrke, A. (1999). Human Security and the Interests of States. Security Dialogue, 30(3), 265-276. https://doi.org/10.1177/0967010699030003002

Tabataba'i Motmaeni, M. (2007). Basic Law (10th ed.). Tehran, Mizan Publication.

Tamushat, K. (2007). Human Rights, Translated by Hussein Sharifi Taraz Koohi, Tehran, Mizan Publication, First Edition.

The United Nations Millennium Declaration. (2004). United Nations Information Center in Tehran, Second Edition.

UNESCO.(2008). Human Security: Approaches and Challenges. Paris: UNESCO Social and Human Sciences Sector.

United Nations Development Programme. (1994). The Human Development Report 1994: New Dimensions of Human Security. New York: Oxford University Press.

\section{Copyrights}

Copyright for this article is retained by the author(s), with first publication rights granted to the journal.

This is an open-access article distributed under the terms and conditions of the Creative Commons Attribution license (http://creativecommons.org/licenses/by/4.0/). 